\title{
The Nexus of Leadership, Political Empowerment, and Social Mobilization: The Case of the July 15 Coup Attempt in Turkey*
}

\author{
RASIM ÖZGÜR DÖNMEZ , KASIM TIMUR**, \\ and FATMA ARMAĞAN TEKE LLOYD ${ }^{* * *}$ \\ * Abdullah Gül University, Turkey \\ ORCID No: 0000-0002-9001-2990 \\ ** Abant Izzet Baysal University, Turkey \\ ORCID No: 0000-0001-8623-610X \\ *** Abdullah Gül University, Turkey \\ ORCID No: 0000-0001-5439-439X
}

ABSTRACT This study analyzes the mutually empowering relations between Turkish President Recep Tayyip Erdoğan and his followers, and how Erdoğan's charismatic leadership and image functioned to galvanize his followers on the night of July 15, 2016, when large numbers of them mobilized against the attempted coup. The article has three sections. The first is a theoretical discussion which sheds light on the concept and the underlying mechanisms of political empowerment and its effects on the relationships between leaders and followers. The second section evaluates Erdoğan's characteristics and ruling style, which was instrumental in motivating resistance to the abortive coup. Finally, the third section analyzes the various means by which Erdoğan was able to inspire the masses to mobilize against the armed junta through interviews and observations. 


\section{Introduction}

O n the night of July 15, 2016, Turkey witnessed a failed coup attempt headed by a small group of soldiers who were allegedly linked to a transnational Islamic sect -the Fetullah Gülen community, also known as the Fetullah Terror Organization (FETÖ) within the Turkish security discourse. Although this coup was not the first to occur in Turkish political history, the street demonstrations which began immediately after the onset of the attempted coup, and the dynamics that made the attempt possible in the first instance, were quite novel in the socio-political context of the country. The telephone appeal on the part of President Recep Tayyip Erdoğan on CNN Türk on July 16 at 00:24 a.m. to his followers to resist the coup détat resulted in a significant outpouring as thousands of people mobilized to rally against the military junta. Many civilians stood up against the guns, tanks, and bombs, and many of them braved bullet fire as well. As a result, 248 people died and 2,196 were injured during the abortive coup. ${ }^{1}$

There have been some important studies focusing on the motivations of those who took to the streets on the night of July $15 .^{2}$ These studies emphasize the fact that Erdoğan's speech on that night and popular perceptions of the coup, as having been orchestrated by internal and external threats -FETÖ and the U.S., respectively- were important motivating factors. By drawing upon and expanding the focus of these studies, this article argues that, although Erdoğan's televised appearance and the speech he delivered on that night played a significant role in building up the confidence of the coup resistors, these are not sufficient as a means of explaining the mobilization that occurred that night. Instead, the pro-system mobilization must be understood in the context of the empowerment that has been mutually constructed between Erdoğan and his followers over the last two decades. Drawing upon the existing literature on leader-group interactions, this study analyses the empowering relations between Erdoğan and his followers, and how Erdoğan's charismatic leadership ${ }^{3}$ and image functioned to galvanize his followers on that fateful night. The authors are interested particularly in how participants in the demonstrations felt empowered by Erdoğan to resist the armed junta and what motivated them to do so.

There has been recent effort on the part of leadership researchers to complement the focus on leadership traits with an analysis of the construction of an in-group social identity that is shared between the leader and the masses. ${ }^{4}$ The central premise underlying this recent approach is that the effectiveness of leaders and their ability to rally the support of the masses depends largely upon whether they are able to create a shared social identity - a 'we' rather than an 'I'. Charismatic authority depends upon the perception of a common set of goals and a shared destiny on the part of the masses, who should feel empowered un- 
der his leadership. This article borrows Page and Czuba's definition of empowerment, which is a "multi-dimensional social process that helps people gain control over their own lives... a process that fosters power (that is, the capacity to implement) in people, for use in their own lives, their communities, and in their society, by acting on issues that they define as important." 5
Throughout his tenure in power, Erdoğan has proven to be a great entrepreneur for identity construction and has been successful in persuading the masses of his constructed notions of 'we'

Empowerment is a particularly useful concept for the present study because it allows for a multilevel approach, ${ }^{6}$ not only illustrating the micro-mechanisms of engagement and the motivations of those engaging in social mobilization, but also permitting a discussion of the larger group context as well. The grouplevel analysis is rooted in the organizational/institutional context of the mobilization and extends the analysis by "outlining the group processes and the characteristics and actions of followers as a group." Thus, the concept of empowerment enables an alignment among these two levels of analysis by taking into account both the individual and group dynamics and processes of engagement. Studies that have focused upon relations of empowerment between the leader and their followers have examined the mobilization of ethno-religious communities against the ruling government or political systems ${ }^{8}$ as well as the role of charismatic relationship in fostering political violence. ${ }^{9}$ However, there are fewer case studies examining how leaders - particularly charismatic ones empower and inspire their followers to support political authority in times of crises, particularly in the case of coup détats.

As Burke says, "[l]eadership, after all, is a reciprocal process. By definition, no followers, no leader." ${ }^{10}$ This is the very reason that it is essential to understand the empowering relations between leaders and their followers if we are to cultivate a proper understanding of collective resistance, such as the one directed against the military coup on the night of July 15 . As the purpose of this study is to analyze the role of empowerment in motivating the masses to mobilize against the coup, the authors conducted in-depth and semi-structured interviews with 20 coup resistors as well as unstructured interviews with another 50 coup resistors. Based on the interview data, this article claims that the construction of a specific in-group identity tied to the larger project of "Muslim nationalism" ${ }^{11}$ helped to further a sense of empowerment as well as opposition to the secularist segment of Turkish society and foreign enemies of the country.

The interviews for this study were carried out between October 2016 and November 2017 and began through the authors' personal connections with the 


\title{
Through his speeches and media declarations, Erdoğan has repeatedly promised to carry the values of his followers to the center of the ruling ethos
}

\begin{abstract}
AK Party's (Justice and Development Party, JDP) district head in the İstanbul neighborhood of Esenler. The authors first asked party affiliates to introduce them to those who had participated in the coup-resistance, and, after the initial contacts were made, they reached further interviewees using the snowball method. The majority of interviewees were located in İstanbul and Ankara, the two most impacted cities. Their socioeconomic status ranged from lower middle to higher middle class. Five of the participants in the semi-structured interviews were women -all of whom were housewives except for one who worked in a low-paying job- and 15 were men. After completing the interviews, the authors performed textual analysis of the data in order to locate the common themes which had motivated participants in the demonstrations.
\end{abstract}

The article consists of three sections. The first is a theoretical section that will shed light on the concept of political empowerment, its underlying mechanisms, and its effects on the relationship between leaders and followers in order to understand how the two influence each other especially in times of political crisis. The second section will evaluate Erdoğan's characteristic features and ruling style, which encouraged those who participated in the resistance, to underscore the relevance of the empowerment thesis to the Turkish case. Finally, the third section will analyze, through interviews and observations, the various means by which Erdoğan inspired the masses to mobilize against the junta on July 15.

\section{Political Empowerment: The Exclusive Relationship between Leader and Followers}

Traditional leadership research has paid considerable attention to the personal traits and qualities that mark out great leaders and the role these play in influencing the masses. In order to appreciate the significance of empowering relations in the political realm, it is necessary to first overcome this conventional understanding of charismatic leadership, which Haslam et al. refer to as the "old psychology of leadership." 12 Many of these studies have drawn upon the notion of charisma, which was first utilized by Max Weber in the modern social science literature to signify a mode of authority distinct from the legal, rational, and traditional. According to Weber, a charismatic leader is one possessing the gift of charisma "by virtue of which he is set apart from other men 


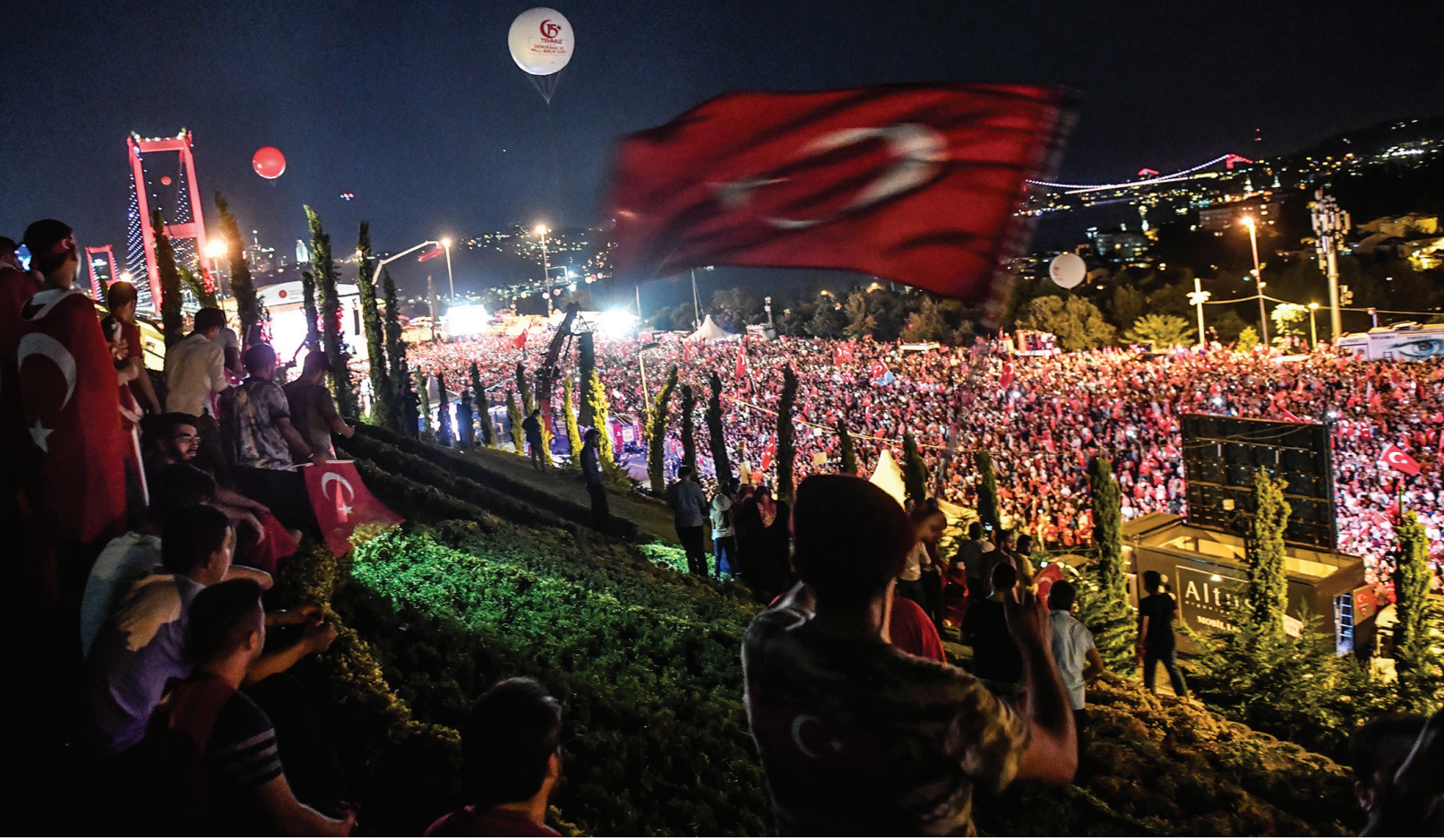

and treated as endowed with supernatural, superhuman, or at least specifically exceptional powers or qualities." ${ }^{13}$ For Shils, extraordinariness is the key concept defining charisma and reflects the "high intensity with which certain vital, crucial qualities are manifested, in contrast with low intensity with which they appear in the ordinary round of life." ${ }^{14}$ Although these perspectives have certainly informed our understanding of the concept, current approaches to the problem of leadership have often failed to identify those specific qualities that are extraordinary and which elevate their possessors to charismatic status.

People gather at the July 15 Martyrs' Bridge in İstanbul to commemorate the July 15, 2016 defeated coup attempt, July 15 , 2018.

BÜLENT KILIÇ / AFP via Getty Images Pappas has usefully distinguished between charismatic leadership and ordinary leadership. While the latter is impersonal and patterned after procedural moderation, the former is always personal and seeks a radical political program. ${ }^{15}$ According to Pappas, there are three hallmarks of political charisma in the context of liberal democracies. The first is that charismatic leaders have an unmediated and direct relationship with their followers. The second is that a charismatic leader usually seeks to attack the political establishment in order to delegitimize it. Lastly, charismatic leaders are often able to secure victories in both symbolic and political battles that ignite new legal and institutional struggles. ${ }^{16}$

Unfortunately many studies of charismatic leadership suffer from being overly leader-centric and ignoring its interactional construction through the mutually empowering relationship between the leader and his/her followers. These studies tend to evaluate charismatic leaders as isolated from their followers, and, to a great extent, ignore how a charismatic leader's behavior manifests 
To understand Erdoğan's relationship with his followers and the role that this has played in his construction of a new Muslim nationalism, the metaphorical significance of the 'family' should not be understated in interactions with the followers and affect their needs. ${ }^{17}$ In addition, some theories of charismatic leadership are based on a heroic leadership stereotype that valorizes these leaders. In this framework, the leader is depicted as a supreme actor, and their followers are perceived as passively bending to the leader's will and commands. Although it is important to understand the conditions and policies

enacted by the leader, it is also true that the followers play a more active part in constructing the leadership role. ${ }^{18}$ After all, the follower is a person who accepts the leader as a source of supervision and motivation without considering any formal relationship. ${ }^{19}$

In order to better comprehend the empowering relationship between Erdoğan and his followers, this article relies on what Haslam et al. refer to as the 'new psychology of leadership. ${ }^{20}$ This relatively newer framework considers both charismatic leaders and their followers as equally active interpreters of the social world. Thus, these studies assert that leaders and followers actively depend upon one another in order to create the conditions in which mutual influence can be realized. ${ }^{21}$ Shamir et al. ${ }^{22}$ found strong links existing among the followers' "self-concepts," ${ }^{23}$ the leader, and their collective mission. In a charismatic relationship, followers identify themselves with the leader, the group, and/or the collective mission, and regard these as the expression of their self-concepts. ${ }^{24}$ Even where the self-concept of a person is diverse or multidimensional, ${ }^{25}$ such a convergence between personal and collective aspects of the self produces a common cognitive structure, which in turn has an impact on how he/she thinks, acts, and interacts.

In this respect, the work of Haslam et al. is especially relevant to the present study since they argue that effective leadership is grounded in a shared social identity. ${ }^{26}$ They specify four conditions that are necessary for an empowering relationship to emerge between the masses and the leader. First, leaders must be seen by their followers as members of the same group. This relationship is cemented not through their individuality but by their being part of a common in-group and one which is opposed to an exterior out-group..$^{27}$ In this sense, shared economic and educational backgrounds, religious and ideological beliefs, and similar attitudes towards political questions such as abortion, use of headscarf, or foreign policy are important as a means of connecting leaders with their followers through a common identity. This is not to say that individual qualities of leaders, such as charisma, are unimportant, but rather that they 
are important only insofar as they reinforce the same in-group identity and are therefore highly contextual. For example, while the leader of an elitist party might reflect his/her charisma in terms of oratorical skills, accent, and intelligence, a more populist leader might do so by cultivating the image of a tough person. Therefore, as Platow et al. suggest, charisma is a gift to be bestowed upon leaders for being representative of 'us.' ${ }^{28}$

Second, Haslam et al. argue that among all of the various leadership traits surveyed in the literature, the most important one, from the perspective of groupleader interactions, is the ability of leaders to represent their actions as advancing the interests of their own in-group. Here, Haslam et al. differentiate their approach from the Leadership Trait Analysis (LTA) developed by Margaret Hermann, which lists seven personality traits that make up a successful leader: (i) belief in their ability to control events, (ii) conceptual complexity, (iii) a need for power, (iv) distrust of others, (v) in-group bias, (vi) self-confidence, and (vii) task orientation. ${ }^{29}$ For Haslam et al., LTA harkens back to the 'old psychology of leadership' approach as it treats leaders as if they were living in a vacuum. Instead, they argue that effective leadership is much more easily reducible to a simple in-group morality according to which the masses perceive their leader as prioritizing the norms and values of their in-group and its material interests over that of others. ${ }^{30}$ Only in this way can they empower their followers in the larger society and garner their unconditional loyalty in return.

Thirdly, Haslam et al. suggest that leaders should "craft a sense of us." In other words, they do not only operate with pre-existing identities that are given to them by others, but they continuously re-craft and re-shape who they and their followers are. This could include befriending old enemies, divorcing themselves from old friends, and convincing the masses to accept the changing nature of their social identity. ${ }^{31}$ The last one is particularly important for leaders in the long run, because a new social identity can be energizing; it renews the loyalty of the masses and provides them with a new framework with which to reproduce their self-identity. Such a continuous flow of support and approval from their followers is also critical since it increases the leader's self-confidence, and, in turn, facilitates a common willingness to self-sacrifice and invests energy in the collectivity and a higher mission. ${ }^{32}$

Fourthly, Haslam et al. suggest that leaders must "make us matter." The task of the leader is not simply to express the group values but to pave the way for the group's advancement of their goals within society. ${ }^{33}$ In an empowering relationship, followers possess "a set of values and clear sense of self," which the political leaders provide to them in order to enable collective action. Followers gain "a sense of direction and self-expression" from the leader's presence, establishing limitations on the leader's power and helping to shape the values conveyed by the leader. ${ }^{34}$ The sense of direction coming from the leader in- 
Erdoğan's success in mobilizing the masses relied on the representation of himself as anti-Western, anti-elite and poor -in other words, cultivating a common identity with the masses of the country, who had been peripheralized by the ruling secularist elite cludes "a higher purpose, a worthy cause, an idea," requiring "collective and concerted effort" and inspiring followers to work toward fulfilling a mission or role. ${ }^{35}$ Empowerment seeks to increase the capacity of an individual to perform their role, and their motivation and dedication toward that role. ${ }^{36}$

Scholars argue that within the context of empowering relationships, popular mobilization to protect the leader and government in times of upheaval becomes much more likely. When an empowering relationship is established between a leader and masses at the group level, followers of the leader achieve cognitive empowerment at the individual level too by developing a sense of self-efficacy. ${ }^{37}$ As defined by Bandura, perceived self-efficacy refers to "beliefs in one's capabilities to organize and execute the courses of action required to manage prospective situations." ${ }^{38}$ Regarding the notion of empowerment, a high perception of self-efficacy increases followers' confidence that success is possible. Similarly, Thomas and Velthouse formulated a broader definition of empowerment as "an intrinsic task motivation," whereby empowerment indicates both the capability of an individual to execute his or her role and the effort of the individual to adhere to that role. ${ }^{39}$ According to them, if an individual or group is intrinsically motivated (namely empowered), supervision by others or rewards are not necessary for right behavior. ${ }^{40}$ In the absence of supervision empowered individuals may act towards a higher purpose or ideal, and demonstrate "flexibility in controlling their own task accomplishment, initiation of new tasks as problems or opportunities arise, and resiliency to obstacles, sustaining motivation in the face of problems and ambiguity." ${ }^{\prime 1}$ According to Howell and Shamir, individuals who feel empowered through their shared identity with the leader will mobilize easily because they will "(i) find meaning in their role involvement, (ii) feel efficacious with respect to their ability and capacity to perform, (iii) have a sense of determination, and (iv) believe that they have control over desired outcomes and can have an impact on the environment." 42

The analysis of Erdoğan's leadership style has been undertaken by a number of scholars, primarily using the LTA method. For example, Çuhadar et al. compared Erdoğan's leadership traits with those of former president Turgut Özal in order to explain the different foreign policy outcomes that resulted during the two Iraqi wars (in 1991 and 2003), and, specifically, the debate over stationing U.S. troops on Turkish soil under similar structural constraints. They suggested 
that, compared to Özal, Erdoğan evinced lower levels of conceptual complexity and self-trust, which prevented him from managing the decision-making process effectively. ${ }^{43}$ Also utilizing the LTA method, Görener and Ucal argued that Erdoğan's low conceptual complexity and higher self-trust, as well as his desire for power, have rendered him a confrontational figure in foreign policy -what they describe as an evangelical type of leader. ${ }^{44}$ Kesgin reached a rather different conclusion by using the LTA method, as he argued that Erdoğan possessed a higher conceptual complexity and lower self-trust compared to other leaders in the region, which led him to pursue an assertive policy domestically and a more collegial approach abroad. ${ }^{45}$ This article differs from these studies in that it focuses on analyzing the empowering relationship between Erdoğan and his primary constituency, namely the Muslim nationalist community, rather than simply examining Erdoğan's leadership traits. However, it will refer to these leadership characteristics wherever they are relevant to the discussion.

\section{Erdoğan and His Followers: Construction of an Empowering Relationship}

One of the most prominent aspects of Erdoğan's rise to power and dominance within Turkish politics has been his ability to construct an empowering relationship between himself and his followers by assuming the mantle of the poor and under-represented religious masses. In his recent book Çağaptay argues that in order to understand Erdoğan's political success, it is important to situate it within the context of Turkey's historic secular establishment, and the mistreatment he faced as a pious man at the hands of Turkey's Westernized elite. ${ }^{46}$ Erdoğan's political journey started in the National Outlook Movement (Milli Görüş) and continued with his becoming the mayor of İstanbul in 1994 and prime minister in 2003 with his newly established AK Party. The paramount political strategy underlying all of the political movements he was involved in was populism and a stark division between the secularists and Muslim population of the country. The AK Party was populist in the sense that "a personal leader appeals to a heterogeneous mass of followers, many of whom have been excluded from the mainstream of development." ${ }^{47}$ Erdoğan's success in mobilizing the masses relied on the representation of himself as anti-Western, anti-elite and poor -in other words, cultivating a common identity with the masses of the country, who had been peripheralized by the ruling secularist elite. In this regard, the party's populism and politics cannot be separated from Erdoğan's characteristic features and ruling style.

According to Haslam et al., it is important that leaders share a common background with the larger society since this serves to cement their relationship with their followers and to enhance their charisma as well. Erdoğan's socioeconomic background has enabled him to connect with the masses profoundly. 


\section{Erdoğan has sought to empower his followers by formulating higher-order goals according to their fundamental demands}

He was born in Kasımpaşa, a lower-middle-class neighborhood in İstanbul. According to Heper, the place was very well known for its conservative ethos with a "deep sense of solidarity among its lower income classes; a cultural pattern that Erdoğan has displayed in his life." 48 This background would clearly disassociate him from Kemalist modernism, and particularly the secular and Western-oriented middle-class segment of the society, affording him the ability to better connect with the lower economic strata. Moreover, his educational background, particularly his study at a Prayer Leader and Preacher School (Imam Hatip Lisesi), played a formative role in the development of his personal characteristics and way of thinking with respect to politics and society. According to Heper, what he received from this education was a hybridization of religious and secular virtues and attitudes, namely, "patriotism, love for fellow human beings, service for the country, worship of Allah, environmental sciences, spirit of solidarity." ${ }^{49}$ Indeed, it is these features which best encapsulate the definition of Muslim nationalist identity.

Throughout his tenure in power, Erdoğan has proven to be a great entrepreneur for identity construction and has been successful in persuading the masses of his constructed notions of 'we.' In his speeches, he has been very careful about acting and speaking from within the community. He generally uses the "we" pronoun instead of "I." This preference suggests both his emotional attachment to the larger group, as well as his exhortation to his followers to overcome their own petty self-interests for the sake of the collectivity through social identification with their leader. Erdoğan's pious character and Islamist views have constituted the main channel through which he has established a shared identity between himself and his followers. Islam, which he perceived as the source of morality and other virtues, has always been a paramount reference point both in his political and private life. In constructing this Islamist identity for the nation, Erdoğan has explicitly distanced himself from the internal 'other', namely the secularist Westernized Turks, who formed the elite backbone of the country and enjoyed a life of plenitude at the expense of the religious masses. In order to demarcate the in-group/out-group boundaries and suggest that his life experience places him within their own group, Erdoğan frequently narrates to his followers their past suffering at the hands of the Kemalist elite. According to Heper, Erdoğan believes that those who consider themselves as secularist (laik) do not accept Islam as the source of morality. ${ }^{50}$ His vision of the political and social spheres is based on central dichotomies such as moral 


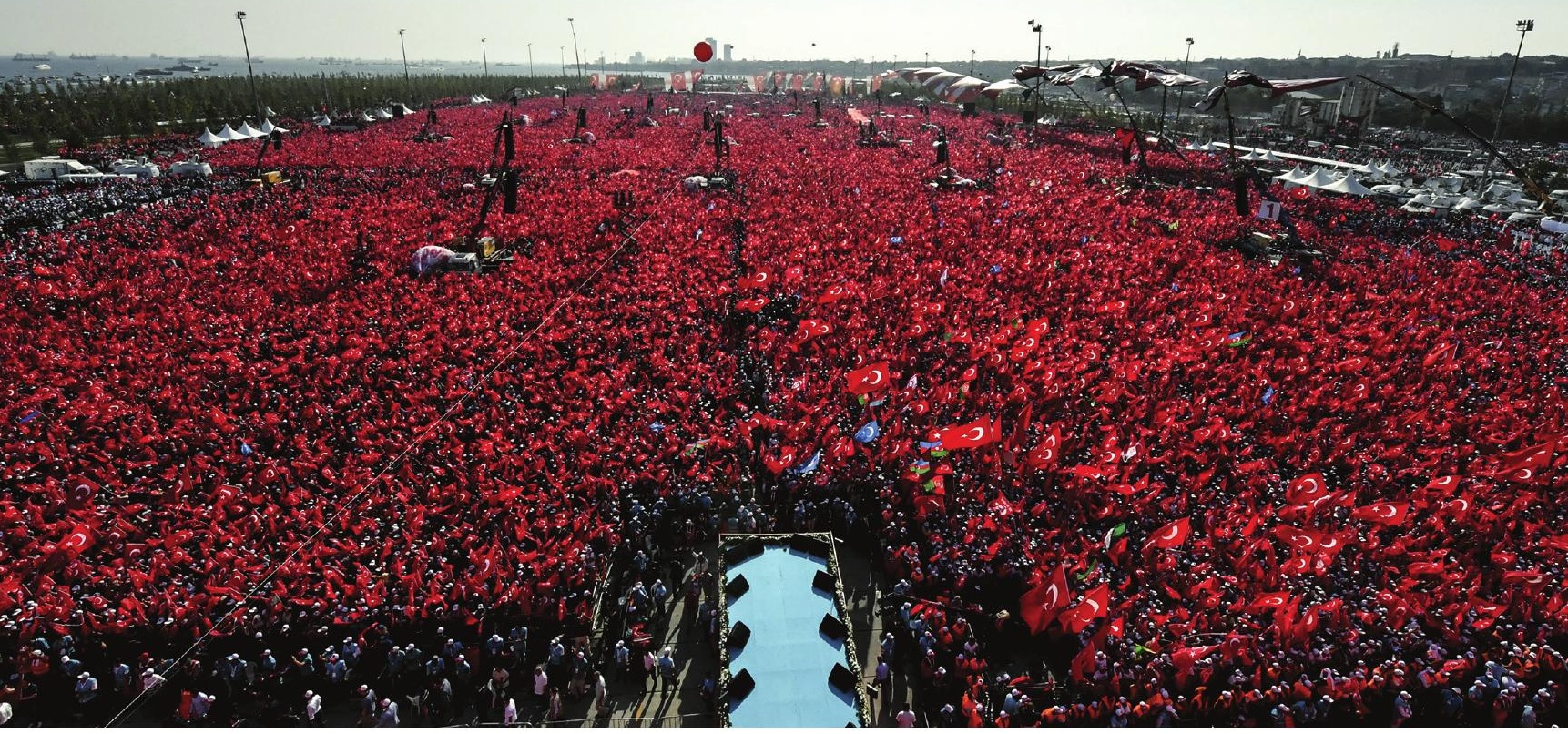

vs. immoral, pious vs. secular, and he believes that the nation must be firmly in the hands of his pious and moral constituents.

In constructing this shared identity, Erdoğan has also found himself in a seemingly intractable contest with those who would seek to undermine the interests of the group he identifies most strongly with -that is, the conservative Muslim masses. Görener and Ucal's analysis reinforces this perception. ${ }^{51}$ According to them, Erdoğan has a low conceptual complexity, ${ }^{52}$ tending to see the world in black-and-white terms and avoiding ambiguity at all costs. In this regard, he also has a strong tendency to make a stark distinction between 'us' and 'them,' yielding to categorical thinking on most matters. According to Çarkoğlu and Kalaycıoğlu, Erdoğan's charismatic leadership is largely a function of his tendency to interpret the world through a polarizing lens, which has great resonance for many of his followers. Based on their surveys at the grassroots level, Çarkoğlu and Kalaycıoğlu have observed that Turkish conservatism has a strong tendency to eschew skeptical judgment, favoring simple binaries. Their research demonstrates that Turkish conservatives believe somewhat dogmatically in a single all-encompassing truth: "of all the different philosophies which exist in this world there is probably one which is correct." 53

As Haslam et al. point out, representing the voices of the masses is only the first step in building an empowering relationship, and the leader should also favor the symbolic and material interests of the in-group, based on their particular norms and values. Erdoğan has been a very successful leader in terms

In the Democracy and Martyrs' Rally people hold Turkish flags to protest against the July 15 coup attempt orchestrated by the FETÖ, at Yenikapı in İstanbul, Turkey on August 7 , 2016.

KAYHAN ÖZER / AA Photo 
During the AK Party's rule, the gains from economic growth have been distributed more widely, leading to decline in poverty and rise in median

\section{income}

of safeguarding the interests of his own in-group relative to other outgroups and this is true, both at the symbolic and material levels. Erdoğan depicts himself as the 'big brother' of the nation, and particularly to those people on the periphery. Through his speeches and media declarations, Erdoğan has repeatedly promised to carry the values of his followers to the center of the ruling ethos. Erdoğan's discourse has aimed to reconstitute this relationship of government to irrevocably alter it by framing "social expectations within a religious and conservative discursive formulation." ${ }^{54}$ During the course of Erdoğan's rule, Turkey has experienced Islamization both within domestic politics and external relations, particularly after his consolidation of power in the 2011 elections. ${ }^{55}$ Criticizing 'old Turkey' for being Westernized and alienated from its Islamic roots, Erdoğan adopted a strategy to foster improved relations with the Islamic world of the Middle East and Africa. ${ }^{56}$ From his defense of Palestinian interests in international forums to his support for the Muslim Brotherhood, the increased international aid to poor Muslim nations, and closer business and diplomatic ties with Muslim countries, he has also sought to appeal to the conservative masses who have long sought for Islam to assume a more central place in political life.

To understand Erdoğan's relationship with his followers and the role that this has played in his construction of a new Muslim nationalism, the metaphorical significance of the 'family' should not be understated. ${ }^{57}$ Indeed, the likening of the nation to a large extended family has been a staple of many different nationalist movements throughout history. According to this perspective, loyalty to the nation is akin to the loyalty within the family, and national solidarity is ultimately based upon familial ties. ${ }^{58}$ Accordingly, Erdoğan has assumed the role of a patriarchal figure -a big brother or father of the family-guiding and sheltering the "new" nation. ${ }^{59}$ According to Çarkoğlu and Kalaycıŏlu, the AK Party constituency is characterized by lower levels of self-esteem, indicating the extent to which individuals value themselves as members of the larger society. ${ }^{60}$ This makes the leader-as-big brother or leader-as-father archetype crucial inasmuch as this enables Erdoğan's followers to buttress their self-esteem and guard themselves against uncertainty and perceived threats.

In the empowering relationship between Erdoğan and the conservative masses, the economic and social policies pursued by the AK Party, which have favored the poor and lower income groups (who also tend to be more religious), have been critical. During the AK Party's rule, the gains from economic growth have been distributed more widely, leading to decline in poverty and rise in 
median income. ${ }^{61}$ For the poorer segments of Turkish society, municipalities and charities (vakıf) have provided in-kind economic support including food and fuel, while Erdoğan has also instituted social policies to support the education and health care needs of these groups. ${ }^{62}$ The opportunity to pursue higher education, which is regarded in Turkey as the principal path to social mobility, has also vastly improved thanks to the increased number of public universities and the growth of private universities, which have been supported by a newly emergent religious capitalist class. Feelings of greater competence and selftrust have also increased among religiously conservative businessmen, who have developed better trade connections abroad through Islamist business associations like Independent Industrialists and Businessmen Association (MÜSİAD) and who have considerably increased their share of profit-yielding investments by investing heavily in public projects. ${ }^{63}$ Erdoğan's economic and social policies have garnered him greater loyalty amongst his followers because these demonstrate his own fidelity to 'his family' and their interests. According to Görener and Ucal, Erdoğan is a low-task-focused leader, ${ }^{64}$ and is more concerned with satisfying the expectations and opinions of his followers than with realizing some predefined agenda. ${ }^{65}$ Indeed, there appears to be a reciprocal relationship between the ruler and the ruled; as Çarkoğlu and Kalaycioğlu's analysis of the AK Party constituency demonstrates that Erdoğan's supporters are much more inclined to glorify their leader. ${ }^{66}$

Lastly, it should be emphasized that Erdoğan's frame of reference as to the definition of 'we' and how to serve his in-group has continuously evolved throughout his tenure in power. As mentioned before, Haslam et al. argue that successful leaders must not confine themselves to social identities that are handed down to them but constantly renew these according to the changing political context. Throughout his rule, Erdoğan has constantly defined new enemies, whether it be secular establishment, the West, the military-secular elites of Turkey, the Gezi protestors, journalists, companies, or, lately, FETÖ. According to Türk, Erdoğan has garnered the support of the excited masses by employing an antagonistic discourse. ${ }^{67}$ Phrases such as "stand up," "hey," and others signify the big brother or father of the family demanding that his opponents be held accountable by his followers. He has sometimes invoked this language when berating European countries or their leaders, and at other times with respect to the Turkish military and judicial system, which initially sought to eliminate him from politics. In depicting the behavior of Turkish military as the enemy of democracy during the Sledgehammer and Ergenekon cases, Erdoğan severely undermined trust in this institution on the part of the public and was able to discredit past coups as an encroachment upon the will of the people. ${ }^{68}$ In another instance during the Gezi protests, Erdoğan called out, "Hey Gezi Protestors, you started a protest for 10 trees. Have you ever planted any tree anywhere?" 69 couching his attacks in a plainspoken everyday language, which would appeal to his supporters. He also did the same when 
criticizing the Turkish Industry and Business Association (TÜSİAD), which he regards as a representative of secular capital: "Sorry TÜSİAD, your demand will not be served but the nation's demand will be realized."70

In 2013, Erdoğan and Fetullah Gülen, the leader of FETÖ, experienced a falling out due to disagreements over power sharing in the country. Gülen had been a stalwart supporter of the AK Party, and had stood by the party during Erdoğan's political struggle against the secular military establishment; however, following their disagreement, Erdoğan asked his followers to disconnect from this movement, which he depicted as a traitor to the nation.

\section{July 15: A Case for Political Empowerment}

The July 15 coup attempt mobilized hundreds of thousands of people, who took to the streets in order to resist the junta. To explain this unique case, this section will attempt to address two cardinal questions: Is there any evidence that the empowering interaction between Erdoğan and his supporters had an impact upon the July 15 mobilizations? How did Erdoğan empower his followers to resist against the armed junta?

In order to provide an answer to the first question, the authors rely upon a survey carried out by the public opinion research group KONDA. According to this survey, 13.2 percent of people attended the demonstrations in Turkey prior to Erdoğan's speech (approximately one-third of those who claim to have taken part). After the President called upon the people to go out into the streets on CNN Türk around 00:24 a.m., this figure doubled to 26.6 percent. Others either stated that they took to the streets on the next day or never. ${ }^{71}$ One participant, who went out prior to Erdoğan's speech on the night of July 15, described the scene as follows: "We went to the streets, and there weren't very many of us. After Erdoğan's speech, people saw that Erdoğan had not been murdered, and they became hopeful, and thousands of people joined us." A 27-year-old chemist who was also present shared his observations in an interview published by BBC Turkish: "I came out at the first moment, but there was no reaction from the President yet. ... Erdoğan's upright stance in every crisis gave people courage. They trusted him, they said, 'I have a president."'72

Almost every participant who went out on the night of July 15 had some relationship with the AK Party, as either a member or sympathizer. According to the present authors' observations in the field, however, there were also a comparatively smaller number of people defining themselves as members of the Nationalist Movement Party (MHP). ${ }^{73}$ However, almost all participants identified with the larger Muslim nationalist project and its values. Those with whom the authors carried out semi-structured interviews also defined them- 
selves overwhelmingly as patriotic and pious. For example, a 44-year-old male participant expressed this in the following terms: "Our leader's call was the best invitation for a people believing in Islam and able to protect the unity of the nation."

According to the authors' interview data, the empowering relations between Erdoğan and his followers were crucial in the mobilization of people on the night of July 15 . The factors that motivated participation in the demonstrations can be grouped under four main headings: i) anxiety over losing their gains under AK Party rule, ii) the protection of Islam in the country which was linked to the survival

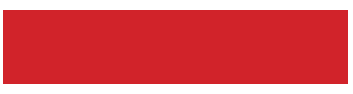

\title{
The July 15 coup attempt mobilized hundreds of thousands of people, who took to the streets in order to resist the junta
} of Erdoğan, iii) a strong cathexis to the regime and its symbols, and iv) the impact of the leader's speech, and, particularly, the desire to thwart the country's 'enemies' -i.e. FETÖ and Western powers.

When they first heard of the coup attempt, all participants felt frustration and perceived this immediately as a threat to their own group identity, which was closely connected to Erdoğan himself. Being the chief architect of Muslim nationalism in the country, Erdoğan has served as a vehicle for conveying his followers' thoughts and as an agent to procure for them tangible assets, both material and symbolic. Erdoğan has sought to empower his followers by formulating higher-order goals according to their fundamental demands, such as lifting the headscarf ban in the public sphere and developing the country and making it prosperous. His success has also motivated and validated the experiences of his followers, with respect to both moral and economic matters. A 22-year-old male university student stated:

\begin{abstract}
Erdoğan is a leader gaining the hearts of the people from 7 to 70 years old. Apart from this, all women in my family wear a headscarf and suffered from this in the past. When my father and mother were engaged, my father was requested to take an official document from the recruiting station, but my mother was not allowed to enter a military building due to her headscarf. Tayyip Erdoğan became the healer of many people like my mother.
\end{abstract}

As mentioned previously, Erdoğan's government has invested heavily in social programs targeting the poor, subsidizing food, healthcare, and education through charitable organizations, and has provided employment to conservative sectors of the society, particularly through the state. The AK Party inherited the neo-patrimonialist traditions of the country that were firmly established after the 1980 coup deetat and the 1982 constitution, which obstructed the development of strong labor movements and mass party organizations, 


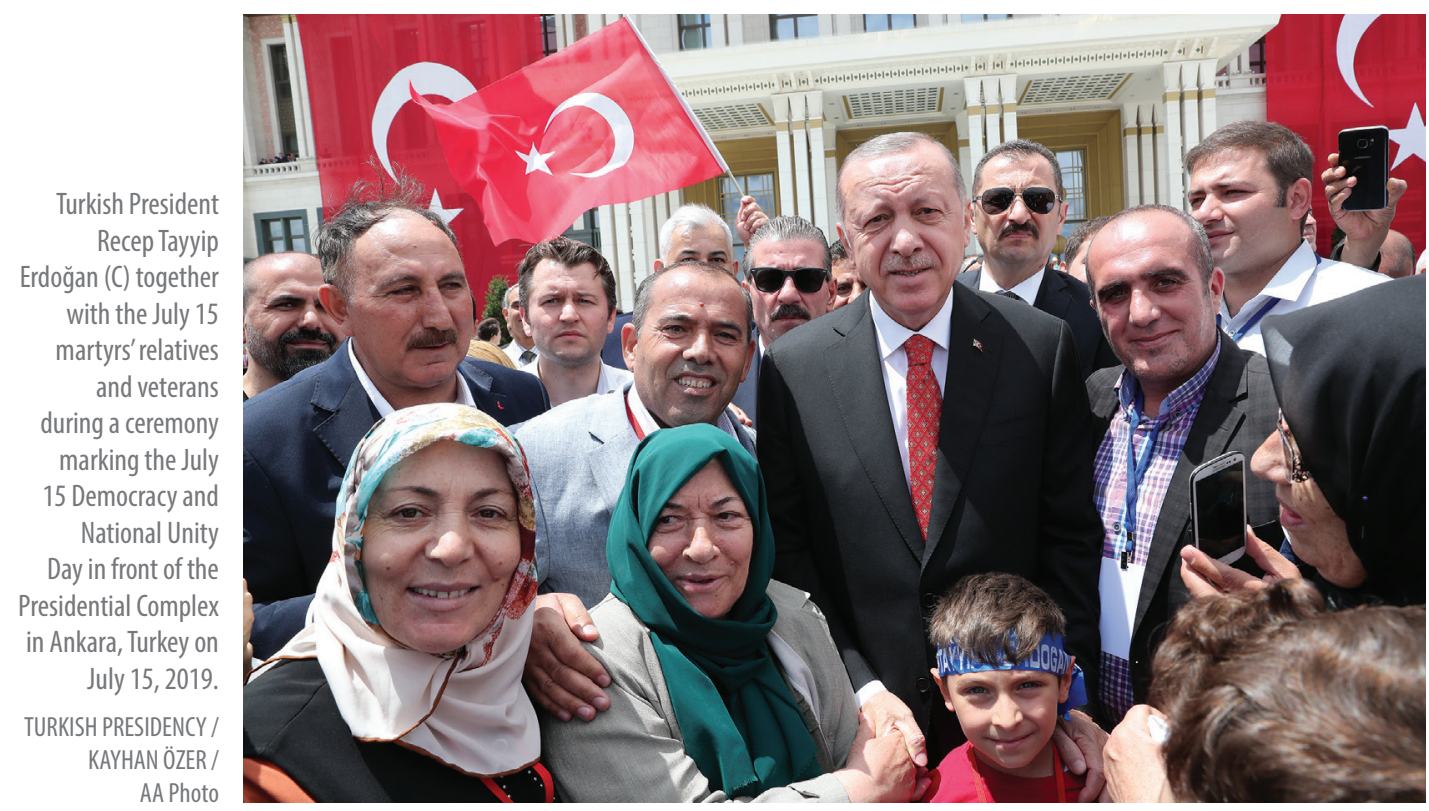

while state interventions and market reforms have dramatically weakened mass organizations and civil society. ${ }^{74}$ Erdoğan's one-man leadership style has allowed him to arrogate so much political and economic power in his own hands that the regime has become identified with him personally (what is known as "Erdoğanism") and this has not gone unnoticed by his followers. A 54-year-old male participant said:

We went outside to prevent the coup for two reasons. The first is our patriotism. If we did not stop the coup, our country would have retrogressed 20-30 years in economic, social, and political terms. The second is that our leader protects [from others in economic and social terms] and leads us. We have an emotional bridge with him. We read his heart and went outside before listening to him on the television.

In this regard, the coup attempt, particularly following Erdoğan's speech, evoked great anxiety and anger amongst his followers. Initially, the majority of interviewees perceived the coup as a threat to their identity but when inquired further, it becomes clear that they were motivated more by the threat of material and symbolic loss. A 36-year-old academician, who defined himself as an Islamist, stated, "When I think about why we were getting frustrated and anxious now, I think it is a fear of losing gains. The state transferred a huge amount of money to Islamic civil society organizations. We would lose this chance." As used herein, the pronoun "we" explicitly refers to a social identification with the current political order and government through the facilities 
allocated to Islamic civil society. Since the social identification is attributed to the self-definition of an individual in terms of salient group memberships, the individual experiences the successes and failures of the affiliated group as his/her own. ${ }^{75}$ Even if the identification process does not necessarily describe a specific behavioral or affective outcome of cognition, it can be said that the loss of the affiliated group in this case was seen as a loss of empowerment within a wider framework, and not merely as an economic loss.

There is a long and contentious history of struggle between Kemalist secular-modernism and Islamic civil society. However, in the aftermath of the 1980s, and especially under AK Party rule, Islamic civil society has shaped its relations with the political system in harmony, not by conflict, ${ }^{76}$ and, in parallel with this political reconciliation, it has expanded its reach within the social and economic sphere through religious charities. Unlike the Gramscian dichotomous understanding of civil society/ political society (or state) relations, ${ }^{77}$ the electoral victory of the AK Party in 2002 has opened a space for the articulation of a distinctively state-Islamic civil society. At first glance, as Combaz and Mcloughlin noted, "[c]ivil society mobilisation is a way of supporting citizens' political empowerment by amplifying their voices." ${ }^{38}$ However, in addition to supporting and empowering citizens, this articulation has also helped the AK Party to consolidate its power as a self-empowerment exercise against rival parties.

All interviewees maintained that they believed the coup would undermine their symbolic and their material gains, as well as their future prospects. A 23-year-old university student remarked, "When I first heard of the coup attempt, I felt anxious about the country, myself, my school life." Similarly, another participant (34-year-old) stated, "When I first heard of the coup attempt from my friend through a WhatsApp message, he wrote that everything was finished for me and I would lose everything." For many interviewees, Erdoğan was seen as fundamental to the larger regime. As a 36-year-old male participant expressed, "We are sometimes disappointed by Erdoğan's policies and get angry with him. Sometimes, we did not vote for the AK Party, but at the end of the day, we know that we cannot maintain this system if something happens to him."

These personal narratives attest to the concern on the part of participants over the disintegration of the socio-political system and the loss of their charismatic leader and father figure, Erdoğan. This is also manifest in the results of the 
KONDA survey. When participants were asked about the primary target of the coup, 43 percent believed that it was President Erdoğan, 24.3 percent the state, 9.4 percent the republic, 8.6 percent the ruling party, 7.1 percent democracy, 5.9 percent citizens, and 1 percent the parliament. ${ }^{79}$ As is evident from these results, most of those who took part in the demonstrations saw the coup as an attack on the system and its leader, both of which they were heavily invested in. A 40-year-old male worker stated, "If something happened to Erdoğan, it would be like something was happening to my father... It would be a disaster for our nation... He has the role of a father who makes us prosperous and provides for our needs."

Strong emotional attachment to the leader-as-father and the fear of losing him (and the system itself) obviously strengthened the resolve of Erdoğan's followers and helped them to overcome some of the fear that they would have experienced in the course of protesting. A 34-year-old female veteran's words expressed this succinctly:

I learned of the coup attempt on television. The tanks occupied the streets. I went outside to learn what was going on, and I went to the Bosphorus Bridge near where the junta was blocking the bridge. I asked the commander, pseudo-commander, why they were blocking the Bosphorus Bridge... my Bosphorus Bridge... I told them they did not fear me.

Her reference to "my Bosphorus Bridge" underscores the extent to which regime supporters like her had identified with the political system and the likely sense of loss they would have experienced in the event that the coup had succeeded.

Another mechanism by which Erdoğan sought to empower his followers was through their shared religious affinity. Many participants in the demonstrations employed a cosmological discourse ${ }^{80}$ patterned on a war between good and evil in narrating the events of the coup. They perceived their mobilization as necessary to safeguard the country's independence and their aim was to prevent the colonization of Turkey and to realize the unity of the nation, Islam, and the state. A 35-year-old lady remarked, "I am proud of this nation. We are a beautiful ummah of the Prophet Muhammad... We fought together with sisters who don't wear the Islamic headscarf and brothers who drink... Faith can only be measured with love towards the homeland." A 50-year-old man conveyed his feelings: "There are millions of people who can sacrifice their lives for their religion, homeland, flag, nation, and state. They [the West] cannot operate from outside anymore-Turkey will be getting better."

The cosmological discourse employed by the participants was infused with anti-colonial and Occidentalist undertones in that they perceived the July 15 
collective action as universal in scope and intended to give voice to all oppressed people of the world, and particularly Muslims. For many participants, their Turkish identity was constructed against the image of the West. For example, thousands of people marching against the junta in Taksim

Erdoğan's biography, pious image, and leadership style have increased confidence in him and enhanced the self-efficacy of his followers Square recited the hymn that is believed to have been chanted by the Prophet Muhammad and his companions during their conquest of Mecca. ${ }^{81}$ A 36-year-old housewife remarked,

I was proud of the resistors, who were the beautiful members of the Prophet Muhammad's ummah... Erdoğan did not run away from the attempt. He invited us Muslims to a holy cause for the sake of God and the motherland... The motherland is a road to be constructed to reach Allah.

As is evident from this discourse, the coup plotters were not perceived as being members of the Turkish community or even as Muslims. The parameters of Muslim nationalist identity correspond to a large extent with Erdoğan's own carefully cultivated image -namely, pious, brave, and standing beside the disadvantaged sectors of society against the powerful Westernized elite, the secularist middle class, and the West. In this regard, his image serves to channel the will of middle class Muslim nationalists. A 42-year-old male interviewee defined Erdoğan as follows:

He is well educated in the moral and religious sense, so he is a real leader. He is brave enough to say "one minute" to the cruel. ${ }^{82}$ While he was opposing the cruel [the junta and the West, particularly the United States], he cried for people dying in the streets. He did not run away that night and betray us.

Erdoğan's invention of new symbols and definitions has further functioned to empower his followers. Throughout his struggle against the military establishment, Erdoğan depicted this institution as thoroughly anti-democratic and operating against the will of the people. The followers of Erdoğan felt empowered by this democratic discourse because their voice and concerns were finally represented on the political scene. In the authors' interviews, participants were emphatic in opposing the junta's threat to the majoritarian democracy that had been established in the country. They felt emotionally and materially bound to the state and the political system embodied by Erdoğan. According to his followers, the removal of Erdoğan from political power would constitute a perversion of the country's democratic identity and the capture of the state by foreign powers. The participants rewrote and reframed political concepts in connection with their identity. Thus, the coup attempt was perceived as a threat to their power in society and inspired a higher purpose, a worthy cause, 
and idea, that required collective action to ensure its defeat. In this regard, participants not only struggled to resist the junta but to protect the symbols of the regime that had given them meaning. For example, when asked what democracy meant for him, a 28-year-old man replied:

Do you know what democracy is? Can you simply define this as the right to elect and to be elected? In fact, no! Democracy is what our martyr Mehmet Şefkatlioğlu did. He went outside to resist the junta with his wife. He was murdered, and his wife was injured. Democracy is what he did: dying for his flag, the state, and standing up to the tanks.

Erdoğan's speech on the night of July 15 performed a critical role in empowering his followers, leading them to believe that they themselves could prevent the coup and they were further galvanized after learning that this had been organized by the Gülenist 'enemy'. When they first learned of the coup attempt prior to Erdoğan's speech, a considerable number of people went outside to demonstrate but without any clear plan or strategy. A 34-year-old male participant said, "When I first heard about the attempt, I told my family that it was street time -I had thought that I would never believe in realizing something through street politics."

Following Erdoğan's speech, which was broadcast at 00:24 a.m., hundreds of thousands of people took to the streets. His words were, "This coup was attempted by a small minority in our military... by a parallel organization [indicating the Gülen community as a cabal]. I invite my nation to the squares of our cities." Hearing Erdoğan's words and learning that he was alive empowered his supporters in at least two respects. Firstly, they learned that the coup was not supported by the entire military but only a small faction. Secondly, Erdoğan's speech convinced his followers that they possessed the means to defeat the coup plotters. As they believed in Erdoğan's virtue and wisdom as the head of state and guardian of the Muslim nation, they felt confident that they could defeat the junta with his backing. A 34-year-old male participant expressed this in the following terms: "We instantly went into the street without any agenda and knowing nothing. When we heard Erdoğan had talked on television and saw thousands of people mobilized on the streets, we took heart, and we began to believe that we would win this challenge."

More importantly, Erdoğan's followers learned that the junta was connected to the FETÖ, which they perceived as an extension of Western imperialism. This knowledge fueled their determination to thwart the outsiders as loyal members of the nation. When asked about their resistance to the coup plotters, a 24-year-old male university student stated: "We thought that we were not resisting the military; we thought that we were resisting a minority acting illegally and as an extension of the West." 


\section{Conclusion}

This study sought to analyze the mutually empowering relations between Erdoğan and his followers, and how Erdoğan's charismatic leadership style and image served to galvanize his followers on the night of July 15, 2016. Here, empowerment refers to a process leading to the development of a shared identity between the leader and the masses, fostering greater competence, self-efficacy, and loyalty among them. The present study finds that factors such as Erdoğan's biography, pious image, and leadership style have increased confidence in him and enhanced the self-efficacy of his followers. In addition, the construction of a shared Muslim identity further motivated his followers to mobilize against the junta, which was depicted as an extension of Western imperial machinations.

Participants in the July 15 mobilizations were mostly drawn from the new Islamic middle classes and were imbued with strong religious sensibilities and traditional values. Many were Muslim nationalists, either explicitly or implicitly. Erdoğan's charisma derives, to a large extent, from his historic affiliation and continuing social proximity with them. In constructing a shared identity around Islam, Erdoğan has often represented the world in binary terms, as a struggle between secularist elite (also comprising the military establishment) and the Muslim masses; between Western imperialism and Islamic morality; between innocent supporters of the AK Party and traitors like the Gezi protestors or FETÖ. He has also represented himself as the guardian and protector of the economic and symbolic capital of the Muslim masses, and as a genuine father or brother of the conservative sectors of society, as he has helped to uplift their economic and social conditions. By promoting the values and norms of those who felt excluded or marginalized within the society he brought Islam to the center of Turkish politics.

This empowering relationship between Erdoğan and his followers has operated on a number of distinct levels. As the pioneer of Muslim nationalism in Turkey, Erdoğan is perceived by his supporters as the agency through which they couldgain tangible assets, both material and symbolic, and it was primarily their anxiety over losing these gains fueled their resistance to the junta. Their shared Islamic identity and Erdoğan's perceived connection with the religion has served as another vehicle of empowerment. Erdoğan's followers were also motivated to protect the symbols of the AK Party rule and to oppose the assault upon majoritarian democracy by the coup plotters. Lastly, Erdoğan's portrayal of FETÖ as the enemy of the state played a significant role in motivating his followers. Erdoğan's speech on the night of July 15 inspired confidence in 


\section{them and reinforced their opposition to FETÖ, which was depicted as an actor firmly outside the bounds of Turkish national identity and an extension of Western imperialism.}

\section{Endnotes}

* We would like to thank Yusuf Çay very much for his valuable contribution to our data collection.

1. "15 Temmuz Darbe Girişiminin Acı Bilançosu! Kaç Kişi Şehit Oldu?," Sabah, (July 10, 2017), retrieved from https://www.sabah.com.tr/gundem/2017/07/10/15-temmuz-darbe-girisiminin-aci-bilancosu-kackisi-sehit-oldu.

2. Nebi Miş, "Measuring Social Perception of the July 15 Coup Attempt,"Insight Turkey, Vol. 18, No. 3 (September 2016). See, Nebi Miş, et al., Democracy Watch: Social Perception of 15 July Coup Attempt, (Ankara: SETA, 2016), retrieved from http://file.setav.org/Files/Pdf/20160923110812_democracy-watch.pdf.

3. House defines charismatic leadership "as a leader who has a high degree of charismatic effects on followers." See, Robert J. House "A 1976 Theory of Charismatic Leadership," in James G. Hunt and Lars L. Larson (eds.), Leadership: The Cutting Edge, (Carbondale: Southern Illinois University Press, 1977), p. 191.

4. Alexander Haslam, Stephen D. Reicher, and Michael J. Platow, The New Psychology of Leadership: Identity, influence and Power, (New York: Psychology Press, 2010); Robert G. Lord and Douglas J. Brown, Leadership Processes and Follower Self-Identity, (New York: Psychology Press, 2003).

5. Nanette Page and Cheryl E. Czuba, "Empowerment: What Is It?," The Journal of Extension, Vol. 37, No. 5 (1999), pp. 3-9.

6. Steve W. J. Kozlowski and Katherine J. Klein, "A Multilevel Approach to Theory and Research in Organizations: Contextual, Temporal, and Emergent Processes," in Katherine J. Klein and Steve W. J. Kozlowski (eds.), Multilevel Theory, Research, and Methods in Organizations: Foundations, Extensions, and New Directions, (San Francisco: Jossey-Bass, 2000), pp. 3-90.

7. Jane M. Howell and Boas Shamir, "The Role of Followers in the Charismatic Leadership Process: Relationships and Their Consequences," Academy of Management, Vol. 30, No. 1 (2005), p. 109.

8. Sharon E. Nepstad, "Nonviolent Resistance in the Arab Spring: The Critical Role of Military-Opposition Alliances," Swiss Political Science Review, Vol. 17, No. 4 (2011), pp. 485-491; Charles Tilly, "Domination, Resistance, Compliance ... Discourse," Sociological Forum, Vol. 6, No. 3 (1991), pp. 593-602; Eric Selbin, Revolution, Rebellion, Resistance, (London: Zed Books, 2010).

9. Jerrold M. Post, "Narcissism and The Charismatic Leader-Follower Relationship," Political Psychology, Vol. 7, No. 4 (1986), pp. 675-688; Vamık Volkan, “Large-group Identity, Large-group Regression and Massive Violence," International Newsletter of the Group-Analytic Society, Vol. 30 (2005), pp. 8-32.

10. W. Warner Burke, "Leadership and Empowerment," OD Practitioner, Vol. 27, No. 1 (1995), p. 14.

11. Turkey's conservative masses has come to be classified as 'Muslim nationalist' with the rise of political Islam in Turkey during 1980s, to explain the merger of an ethnic nationalism with a privilege given to non-secular, Islam-based societal and political values. Jenny White also used this to signify the increasing size of middle class who define themselves together with their ethnic and religious identity during the AK Party period. Jenny White, Muslim Nationalism and the New Turks, (New Jersey: Princeton University Press, 2014), p. 7.

12. Haslam, et al., The New Psychology of Leadership, pp. 1-21.

13. Max Weber, Theory of Social and Economic Organization, (New York: Oxford University Press, 1947), p. 358.

14. Edward Shils, "Charisma, Order and Status," American Sociological Review, Vol. 30, No. 2 (1965), p. 201.

15. Takis S. Pappas, "Political Charisma Revisited, and Reclaimed for Political Science," EUI RSCAS EUDO European Union Democracy Observatory, No. 60 (2011), p. 4.

16. Pappas, "Political Charisma Revisited, and Reclaimed for Political Science." 
17. Howell and Shamir, "The Role of Followers."

18. Jaepil Choi, "A Motivational Theory of Charismatic Leadership: Envisioning, Empathy, and Empowerment," Journal of Leadership and Organizational Studies, Vol. 13, No. 1 (2006), p. 24.

19. See, Gary Yukl, Leadership in Organizations, (Harlow: Pearson, 2010), p. 24.

20. Haslam, et al., The New Psychology of Leadership, pp. 27-160.

21. Choi, "A Motivational Theory of Charismatic Leadership: Envisioning, Empathy, and Empowerment," p. 28; Katherine J. Klein and Robert J. House, "On Fire: Charismatic Leadership and Levels of Analysis," The Leadership Quarterly, Vol. 6, No. 2 (1995), pp. 183-198.

22. Boas Shamir, Robert J. House, and Michael B. Arthur, "The Motivational Effects of Charismatic Leadership: A Self-Concept Based Theory," Organization Science, Vol. 4, No. 4 (1993), pp. 577-594.

23. Self-concept roughly refers to "identity." According to a dynamic model of self-concept, it is not a singular/static experience but a multifaceted collection of self-representations. For a more in-depth discussion see, Hazel Markus and Elissa Wurf, "The Dynamic Self-Concept: A Social Psychological Perspective," Annual Review of Psychology, Vol. 38, No. 1 (1987), pp. 299-337.

24. Shamir, et. al., "The Motivational Effects," pp. 577-594. See also, Howell and Shamir, "The Role of Followers," p. 99.

25. Constantine Sedikides, Lowell Gaertner, Michelle A. Luke, Erin M. O’Mara, and Jochen E. Gebauer, "A Three-Tier Hierarchy of Self-Potency: Individual Self, Relational Self, Collective Self," Advances in Experimental Social Psychology, Vol. 48, (2013), p. 236.

26. Haslam, et al., The New Psychology of Leadership, p. 64.

27. Haslam, et al., The New Psychology of Leadership, p. 106.

28. Michael J Platow, et al., "A Special Gift We Bestow on You for Being Representative of Us: Considering Leader Charisma from a Self-Categorization Perspective," British Journal of Social Psychology, Vol. 45, No. 2 (2006), pp. 303-320.

29. Margaret Hermann, "Assessing Leadership Style: Trait Analysis" in Jerrold Post (ed.), Psychological Assessment of Political Leaders, (Ann Arbor: The University of Michigan Press, 2003), pp. 178-215.

30. Haslam, et al., The New Psychology of Leadership, pp. 109-137.

31. Haslam, et al., The New Psychology of Leadership, pp. 137-165.

32. Howell and Shamir, "The Role of Followers," p. 106.

33. Haslam, et al., The New Psychology of Leadership, pp. 137-165.

34. Howell and Shamir, "The Role of Followers," p. 106.

35. Burke, "Leadership," p. 11.

36. Howell and Shamir, "The Role of Followers," p. 106.

37. Choi, "A Motivational Theory," p. 28.

38. Albert Bandura, Self-efficacy in Changing Societies, (New York: Cambridge University Press, 1999), p. 2.

39. Kenneth W. Thomas and Betty A. Velthouse, "Cognitive Elements of Empowerment: An 'Interpretive' Model of Intrinsic Task Motivation," The Academy of Management Review, Vol. 15, No. 4 (1990), pp.666681.

40. Thomas and Velthouse, "Cognitive Elements of Empowerment: An 'Interpretive' Model of Intrinsic Task Motivation," pp. 666-681.

41. Thomas and Velthouse, "Cognitive Elements of Empowerment," p. 673.

42. Howell and Shamir, "The Role of Followers," p. 106.

43. Esra Çuhadar, Juliet Kaarbo, Barış Kesgin, and Binnur Özkeçeci-Taner, "Examining Leaders' Orientations to Structural Constraints: Turkey's 1991 and 2003 Iraq War Decisions," Journal of International Relations and Development, Vol. 20, No. 1 (2017), pp. 29-54. 
44. Aylin Ş. Görener and Meltem Ş. Ucal, "The Personality and Leadership Style of Recep Tayyip Erdoğan: Implications for Turkish Foreign Policy," Turkish Studies, Vol. 12, No. 3 (2011), pp. 357-381.

45. Barış Kesgin, "Turkey's Erdoğan: Leadership Style and Foreign Policy Audiences," Turkish Studies, Vol. 21, No. 1 (2020), pp. 56-82.

46. Soner Cagaptay, The New Sultan: Erdogan and the Crisis Of Modern Turkey, (New York: Bloomsbury Publishing, 2017), p. 30.

47. Kurt Weyland, "Neopopulism and Neoliberalism in Latin America: Unexpected Affinities," Studies in Comparative International Development, Vol. 31, No. 3 (1996), p. 5.

48. Metin Heper, "Islam, Conservatism, and Democracy in Turkey: Comparing Turgut Özal and Recep Tayyip Erdoğan," Insight Turkey, Vol. 15, No. 2 (2013), pp. 141-156.

49. Heper, "Islam, Conservatism, and Democracy in Turkey," pp. 141-156.

50. Heper, "Islam, Conservatism, and Democracy in Turkey," pp. 141-156.

51. Görener and Ucal, "The Personality and Leadership Style."

52. Conceptual complexity "is the degree of differentiation that an individual shows in describing or discussing other people, places, policies, ideas or things." Görener and Ucal, "The Personality and Leadership Style," p. 367.

53. Ali Çarkoğlu and Ersin Kalaycıoğlu, The Rising Tide of Conservatism in Turkey, (New York: Palgrave Macmillan, 2009), p. 39.

54. Cemil Boyraz, "Neoliberal Populism and Governmentality in Turkey: The Foundation of Communication Centers during the AKP Era," Philosophy and Social Criticism, Vol. 44, No. 4 (2018), p. 5.

55. Ayhan, Kaya. "Islamisation of Turkey under the AKP Rule: Empowering Family, Faith and Charity," South European Society and Politics, Vol. 20, No. 1 (2015), pp. 47-69.

56. Alexander Murinson, "The Strategic Depth Doctrine of Turkish Foreign Policy," Middle Eastern Studies, Vol. 42, No. 6 (2006), pp. 945-964.

57. H. Bahadır Türk, Muktedir, (İstanbul: Illetişim Yayınları, 2014), pp. 369-374.

58. Umut Özkırımlı and Pınar Uyan-Semerci, "Pater Familias and Homo Nationalis: Understanding Nationalism in the Case of Turkey," Ethnicities, Vol. 11, No. 1 (2011), pp. 66-67.

59. Betul Ekşi and Elizabeth A. Wood. "Right-wing Populism as Gendered Performance: Janus-faced Masculinity in the Leadership of Vladimir Putin and Recep T. Erdogan," Theory and Society, Vol. 48, No. 5 (2019), pp. 733-751. New nation indicates nation dominated by pious Turkish citizens.

60. Çarkoğlu and Kalaycıoğlu, The Rising Tide, p. 94.

61. Ziya Öniş, "The Triumph of Conservative Globalism: The Political Economy of the AKP Era" Turkish Studies, Vol. 13, No. 2 (2012), pp. 135-152.

62. Deniz Yıldırım, "AKP ve Neoliberal Popülizm," in İlhan Uzgel and Bülent Duru (eds.), AKP Kitabı: Bir Dönüşümün Bilançosu, (Ankara: Phoenix Yayinevi, 2009), pp. 66-107; Umut Bozkurt, "Neoliberalism with a Human Face: Making Sense of the Justice and Development Party's Neoliberal Populism in Turkey," Science \& Society, Vol. 77, No. 3 (2013), pp. 372-396.

63. Gül Berna Özcan and Hasan Turunç, “Economic Liberalization and Class Dynamics in Turkey: New Business Groups and Islamic Mobilization," Insight Turkey, Vol. 13, No. 3 (2011).

64. Task focus signifies "the relative emphasis of a variety factors that motivate individual to seek political Office." See, Görener and Ucal, "The Personality," p. 368.

65. Görener and Ucal, “The Personality," p. 368.

66. Çarkoğlu and Kalaycıoğlu, The Rising Tide, p. 39.

67. Türk, Muktedir, pp. 376-378.

68. "Erdoğan:“'Demokrasi Bayramı...,'” CNN Türk, (September 12, 2010), retrieved from https://www.cnnturk.com/2010/turkiye/09/12/erdogan.demokrasi.bayrami/589419.0/index.html. On the impact of this on the mobilization of the masses on the coup night, see also, Nebi Miş, et al., Democracy Watch. 
69. "Erdoğan: Ey Geziciler Hiç Ağaç Diktiniz Mi?," Haber Aktüel, (August 30, 2013), retrieved from https:// www.haberaktuel.com/erdogan-ey-geziciler-hic-agac-diktiniz-mi-haberi-782495.html.

70. "Kusura Bakma TÜSIAD Milletin Arzusu Olacak," Hürriyet, (February 29, 2012), retrieved from http:// www.hurriyet.com.tr/gundem/kusura-bakma-tusiad-milletin-arzusu-olacak-20022138.

71. "15 Temmuz," KONDA.

72. "Darbe Girişimi Sonrası Sokak Hareketlerinin Anatomisi," BBC Turkey, (August, 15, 2016), retrieved from https://www.bbc.com/turkce/haberler-turkiye-37035442.

73. Nebi Miş, et al., Democracy Watch.

74. Nahide Konak and Rasim Ö. Dönmez, “Deconstructing Neopatrimonial System via Humor," in Nahide Konak and Rasim Ö. Dönmez (eds.), Waves of Social Movement Mobilizations, (Maryland-London: Lexington Books, 2015), pp. 59-83.

75. Blake E. Ashforth and Fred Mael, "Social Identity Theory and the Organization," The Academy of Management Review, Vol. 14, No. 1 (1989), pp. 20-39.

76. See, Özge Zihnioğlu, "Islamic Civil Society in Turkey," in Richard Youngs (ed.), The Mobilization of Conservative Civil Society, (Washington: Carnegie, 2018), pp. 39-43.

77. Antonio Gramsci, Prison Notebooks, (New York: Columbia University Press, 2007), p. 75; John Schwarzmantel, The Routledge Guidebook to Gramsci's Prison Notebooks, (London and New York: Routledge, 2014), pp. 199-205.

78. Emilie Combaz and Claire Mcloughlin, Voice, Empowerment and Accountability: Topic Guide, (Birmingham, UK: GSDRC, University of Birmingham), retrieved from https://gsdrc.org/topic-guides/voice-empowerment-andaccountability/supplements/political-empowerment/.

79. "15 Temmuz," KONDA.

80. See also, Bülent Küçük and Buket Türkmen, “Remaking the Public Through the Square: Invention of the New National Cosmology in Turkey," British Journal of Middle Eastern Studies, (2018), retrieved from https://doi.org/10.1080/13530194.2018.1491295.

81. "Darbeye Karşı Mekke'nin Fethi Marşıyla Yürüdüler," Haber7, (July 24, 2016), retrieved from http:// video.haber7.com/video-galeri/73767-darbeye-karsi-mekkenin-fethi-marsiyla-yuruduler.

82. He was talking about Erdoğan's interruption of Israeli President Shimon Peres during a panel at the World Economic Forum in 2009. 


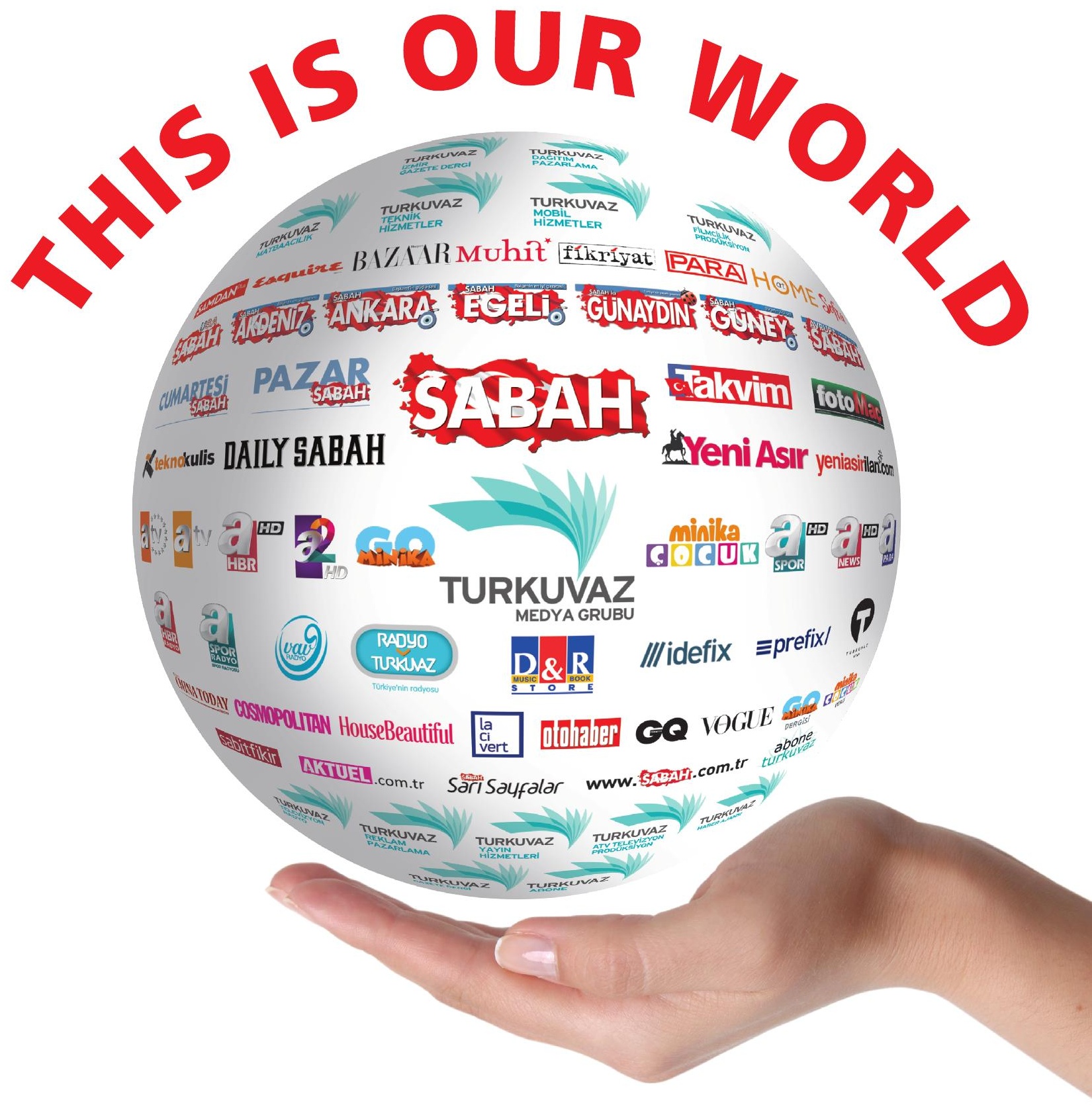

Turkuvaz Media Group is the leading group of companies which deals with broadcasting, publishing and distribution activities in Turkey. Most reputable national and international magazines, best selling local and national newspapers and prestigious tv channels create the most powerful synergy in Turkish media.

The opportunity to utilize this power for your advertisements is in your hands. Why not use it? 